\title{
Factors Influencing the Adoption of Islamic Banking in Malaysia
}

\author{
Paul Anthony Mariadas ${ }^{1} \&$ Uma Murthy $^{1}$ \\ ${ }^{1}$ Faculty of Business, Accountancy and Management, SEGi University, Malaysia \\ Correspondence: Paul Anthony Mariadas, Faculty of Business, Accountancy and Management, SEGi University, \\ Malaysia. E-mail: paulanthonydas@segi.edu.my
}

Received: August 20, 2017

Accepted: September 20, 2017

Online Published: October 18, 2017

doi:10.5539/ijbm.v12n11p187

URL: https://doi.org/10.5539/ijbm.v12n11p187

\begin{abstract}
A nation's economic success is largely dependent on the performance of their banks as they play a major role in regulating its financial sector to stability and cohesion by acting as an intermediary to various parties such as individuals, organizations and governments to conduct their borrowing and depositing activities. The quality of services provided by the banks will influence how these parties benefit and consumers would choose the bank that they perceive will result in the most benefit. In Malaysia, a larger percentage of the population are employing conventional banks compared to Islamic banks due to factors such as unfamiliarity of products and services and inadequate marketing. This study examine the factors influencing adoption of Islamic Banking in Selangor. A quantitative research approach is employed in this research following the positivist assumption with a realist ontology and objectivist epistemology. Data was collected using a probabilistic sampling method, particularly a stratified random sampling technique. The adapted survey questionnaire employed in this study and distributed 150 questionnaire and successfully received 130 questionnaire. Overall, the researcher has discussed about the findings of the analysis that was conucted using the SPSS software. Descriptive approach, correlation and multiple regression analysiss had been shown during the analysis. The descriptive approach displayed direct results while the correlation displayed the relationship between the dependent variable (adoption of Islamic Banking) and the independent variables (compatibility, consumer knowledge, risk perception/management and consumer satisfaction). In this research, found two factors that influencing adoption of Islamic Banking in Malaysia which are consumers knowledge and consumer satisfaction. For the future researchers, this research will benefit them as well. If they are doing their researches which are related to this topic, they can gather everything they want easily. Besides that, it will benefit the researcher who is going to do this research study in Malaysia. This is because the information in Malaysia is limited.
\end{abstract}

Keywords: Islamic banking, consumer satisfaction, compatibility, consumer knowledge and risk perception

\section{Introduction}

The Islamic banking system is well established in Malaysia, currently having 16 Islamic banks and 3 international Islamic banks but still less compared to conventional banking with 27 commercial banks, according to the Central Bank of Malaysia. Consumers in Malaysia have the ease and freedom to choose the best types of banks for their usage. However, there are still many who are not well-informed about the products and services that Islamic bank offers which directly affects the choice of banks of the public (Jamshidi, Hussin, \& Hooi, 2015). Islamic banks have the potentiality to be chosen by consumers.

Islamic banking has become one of the fastest growing industry in Malaysia and conventional banks have to compete with Islamic banking to maintain their market share. They are quite competent in the banking sector and it plays a big role among the service industry in Malaysia today. The introduction of Islamic banking into the banking system has changed the financial landscape by providing a banking system which influences consumers in the religious and social sense. This creates more factors for consumers' selection of Islamic banking. The changing of consumers' tastes have caused them to be able to demand for higher quality products and services. Additionally, Malaysia's dual banking system allows consumers to ask for the banking products and services that most suit their needs. Consumers have more choices to choose from. Thus, conventional banking and Islamic banking have to compete more with each other on the best products and services they can provide to their customers. 
However, Islamic banks are not as widely used by consumers as conventional banks among both Muslims and non-Muslims in Malaysia. The Islamic banking industry are attempting to attract more consumers to improve their market share and achieve more competency among their competitors from the conventional banking industry (Illias, 2012). The services and facilities provided by the Islamic banks has not been completely acknowledged by the consumers in Malaysia. Understanding what makes consumers choose conventional banks over Islamic banks will help Islamic banks achiever a more thorough understanding on customer's perception towards Islamic banks.

Islamic banking follows the Islamic principles of finance to allow Muslim consumers to practice their religion. Thus, Islamic banking is favored by Muslim consumers compared to consumers from of other religion as it helps them to fulfil their requirements to follow the Sharia law in business and transactions. However, there is also a good probability for the growth in percentage of non-Muslim customers in Islamic banking if the benefits are made apparent to them, which will help in the internationalization of Islamic banks (Amin, Isa, Fontaine, 2013). Thus, Islamic banks have to disseminate knowledge about Islamic banking to the public using a more competent system and also create better brand image to achieve a larger market share.

This research is showed by the subsequent questions; (1) what is the relationship between bank customers' standard of living and non-performing loan in Malaysian context? (2) what is the relationship between bank customers' income and non-performing loan in the Malaysian context? (3) what is the relationship between the Malaysian economy and non-performing loan in the Malaysian context? and (4) what is the relationship between banks interest rate and non-performing loan in the Malaysian context?

To seek the answers to these questions, this research will be organized into five (5) sections. Section one captures the introduction, section two discusses review of updated literatures, section three (3) highlights the methodology employed in analyzing empirical data for this research, section four (4) discusses data collection and analysis whilst, section five (5) provides the conclusion and recommendations, as well as the contributions and limitations of the research.

\section{Literature Review}

\subsection{The Definition of Adoption of Islamic Banking}

In this study, the word 'adoption' means to take or follow by choice or assent. Adoption refers to how well consumers are able to receive a product or service as well as how likely they are to use the product or service in the future. The term 'Islamic banking' refers to the conduct of banking activities of financial firms which is in adherence to Islamic teachings (Tara et al, 2014).

This research is titled 'factors affecting adoption of Islamic banking in Malaysia' and it intends to explore the factors influencing adoption of Islamic banking in Malaysia and these factors will be called the independent variable in this study and they include compatibility, customer awareness, risk perception and consumer knowledge. All of these things contribute to the dependent variable which is adoption of Islamic banking in Malaysia. The word 'adoption' means to take or follow by choice or assent. Adoption refers to how well consumers are able to receive a product or service as well as how likely they are to use the product or service in the future. The term 'Islamic banking' refers to the conduct of banking activities of financial firms which is in adherence to Islamic teachings (Tara et al, 2014).

Islamic banking promotes the sharing of profit and loss, giving out zakat, which is expressed as a percentage of $2.5 \%$ from the user's fixed savings to be given to the needy for social benefits and encouraging halal trading or those which are allowed according to the Islamic laws in business. The history of Islamic banking in Malaysia started in 1963 (Saad, 2012). It started when the Muslims in Malaysia found it necessary to establish an official banking system that is based on the Islamic financial systems of trading and investment. Islamic banking is not confined to Muslim user only but also open to users of other religions as well, despite its adherence to the Islamic rulings. Islamic banking customers consist of Muslims and non-Muslims and the reasons on why they choose Islamic banking includes customer satisfaction (Saad, 2012). Thus, Islamic banks have to put focus on customer satisfaction and make them feel comfortable and satisfied with its products and services if they want to attract more users to employ Islamic banking. Therefore, it will be one of the independent variables in this research. Various factors affects the adoption of Islamic banking but as for this research, it will focus solely on compatibility, customer satisfaction, risk perception and consumer knowledge towards Islamic banking.

\subsection{Compatibility}

Compatibility is defined as the degree to which an innovation is perceived as consistent with the existing values, past experiences, and needs of potential adopters (Ganiyu \& Adeosun, 2015). Consumers have various reasons to 
adopt to Islamic banking and compatibility is a big factor. Islamic banking provides many types of products and services and consumers will assess and check whether it will fit their needs and if it matches their beliefs, social system, habits, norms as well as their values and lifestyle (Obeid, 2016). Their beliefs may include how Islamic banking may be better for them and the society as a whole and this will cause them to choose Islamic banking as their choice. It may be because some people believe that the services that Islamic banking provide, such as the sharing of profit and loss instead of the employment of interest, is better for the economy. Some Muslims require for their banking services to avoid the usage of interest and the banks that provide this are providing a service that is compatible with their values. Consumers will follow what their beliefs are and the more compatible to a consumer's need a bank can provide, the more likely it is for the consumer to choose the bank. Islamic banking also avoids doing any trading activities that is related to illegal substances according to the Islamic shariah like alcohol, cigarettes and gambling and some consumers find this rule to suit their values. Compatibility has a significant impact on consumer's adoption of Islamic banking and the more its products and services are compatible with a consumer's beliefs and values, the more the consumers will adopt its usage (Yahaya et al, 2014).

\subsection{Consumer Satisfaction}

Consumers' satisfaction can be defined as customer's rating of the results that they received from doing business with the organization, which results from the consumer's pre-purchase comparison of expected performance with perceived actual performance (Hamzah et al, 2015). It is very important to understand what drives customer satisfaction towards a bank as it is generally regarded as firms' most significant long-term goal, the financial sector included. Customer satisfaction leads consumers to repurchase a product that will lead to the desired outcome of brand loyalty (Sabir et al 2014). The marketing concept suggests that there are higher probability for a buyer to repurchase a product or service when they are satisfied compared to when they are unsatisfied (Kaura, 2013). The increase in competition within the financial services industry that has resulted from the banking companies' services becoming increasingly comparable by the customers has also caused it to be a main factor. Consumers nowadays are able to compare and choose the banks that will give them the most satisfaction regarding to the products and services they offer as there are more consumer buying power nowadays with consumers being more knowledgeable about the marketplace due to increasing technology (Narwal, Sachdeva, 2013).

\subsection{Risk Perception}

Perceived risk can be defined as the level of and nature of uncertainty that the consumers experience in his effort to use a particular product or service (Yahaya et al, 2014). Islamic banking applies banking tasks along with borrowing and lending but without the usage of interest (Illias, 2012) and the lack of interest has caused both benefits and disadvantages to its users. According to the Islamic principles, a user of Islamic banking may receive his benefit in trade and investment as a form of return only if he assumes some risk of his own through the means of risk sharing (Yahaya et al, 2014). While conventional banking uses interest on deposits, Islamic banking applies profit and loss sharing or risk sharing. This means that the borrowers and depositors will uphold some of the risk that the investors make. However, Islamic banking will normally only undertake projects with low risks so as to protect their clients and choose only reliable investment decisions. Credit risk management has to be taken as an important role by Islamic banks if the aim to sustain their customers as it affects the customer's confidence towards the banks and is one of the means that will enable the banks to continue operating. Assuming a lower risk could help Islamic banks to achieve the goal of competency and profitability. This is due to the fact that Islamic banks have forgo interest-based trading which was the practice of conventional banking for several decades or longer.

\subsection{Consumer Knowledge towards Islamic Banking}

The nature of knowledge is complex and it consists of the perspective, beliefs and intention an individual has towards an object or idea (Jiang, Rosenbloom, 2005) and consumers' decision making is greatly influenced by the knowledge that are stored in their memories (Hristov, Kuhar, 2015). Before consumers decide to purchase a product or service, they will use several steps starting with knowledge, persuasion, decision and then confirmation (Safeena et al, 2012). When they have adapted to all of these, they will make the decision whether to accept or reject a product. In the general terms, knowledge about a product consists of a subjective dimension, being the consumer's perception of his own knowledge, and an objective dimension, being the consumer's actual knowledge (Hristov, Kuhar, 2015). The degree of how much a consumer will look into a product is influenced by the consumer's prior knowledge about a product (Jiang, Rosenbloom, 2005). Thus, firms have to make sure that the consumers have the correct understanding about a product so as to avoid making the consumer lose interest 
in the product. Two main components of consumer knowledge are familiarity and expertise (Pillai et al, 2015) and familiarity includes current goals and past experiences which affect a customer's evaluation of a product (Cakarnis, D'Alessandro, 2015). Banks could attempt to familiarize consumers with its products so as to influence product selection.

\subsection{Proposed Framework}

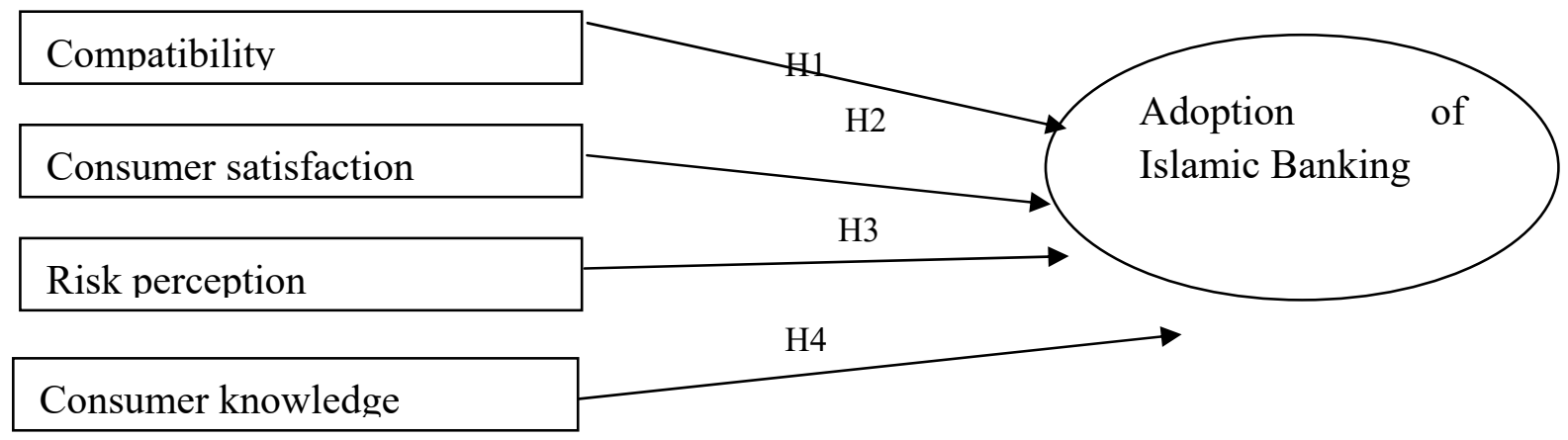

\subsection{Research Hypotheses}

H1: Compatibility will have a direct significant influence on adoption of Islamic banking in Malaysia

$\mathrm{H} 2$ : Customer satisfaction will have a direct significant influence on adoption of Islamic banking in Malaysia

H3: Risk perception will have a direct significant influence on adoption of Islamic banking in Malaysia

H4: Consumer knowledge will have a direct significant influence on adoption of Islamic banking in Malaysia

\section{Research Methodology}

\subsection{Measurement and Collection of Data}

A quantitative research approach is employed in this research following the positivist assumption with a realist ontology and objectivist epistemology. Data was collected using a probabilistic sampling method, particularly a stratified random sampling technique. The adapted survey questionnaire employed in this study is divided into two sections; demography and scales of the four (5) underlying factors of the research instrument, capturing four (4) independent variables and 1 dependent variables. A 5-point Likert scale was used showing (1)"strongly disagree", (2) “disagree", (3) "slightly agree", (4) "agree”, (5) "strongly agree. In general terms, all the variables are showing a reliable result on the Cronbach's Alpha which is 0.700 .

Table 1. Normality Test

\begin{tabular}{|c|c|c|c|c|c|c|}
\hline \multicolumn{7}{|c|}{ Tests of Normality } \\
\hline & \multicolumn{3}{|c|}{ Kolmogorov-Smirnov ${ }^{\mathrm{a}}$} & \multicolumn{3}{|c|}{ Shapiro-Wilk } \\
\hline & Statistic & df & Sig. & Statistic & $\mathrm{df}$ & Sig. \\
\hline Islamic banking & .132 & 200 & .000 & .953 & 200 & .000 \\
\hline
\end{tabular}

The conclusion that can be made from the results that are collected from the Table 1 is that the test of normality from this research for the Kolmogorov-Smirnov test is that the Sig. is normal which is at .000 . The evidence for this is from (Hair et al, 2010) which says that the normal value for the Kolmogorov-Smirnovtest is .000. Thus, this data is normally distributed. 


\section{Data Analysis}

\subsection{Multiple Regression Analysis}

Table 2. Model summary

\begin{tabular}{llllll}
\hline Model & $\mathrm{R}$ & $\mathrm{R}$ Square & Adjusted R square & Std. Error of the Estimate & Durbin-Watson \\
\hline 1 & .350 & .122 & .104 & .32035 & 1.871
\end{tabular}

a. Predictors: (Constant), Bank Interest Mate, Economy of The Country, Consumer Income, Standard of Living

b. Dependent Variable: Non-performing loan

\subsection{Model Summary}

Table 2 shows a Durbin Watson value of 1.871 (within the cut-off threshold of between 1 and 3) which indicates that independent error terms are not correlated. In other words, a Durbin-Watson value of 1.871 implies that there is no auto-correlation of residuals. R-square value of 0.122 suggest that $12.2 \%$ of the total variance in the dependent variable (adoption of Islamic Banking) is explained by the independent variables (compatibility, consumer satisfaction, risk perception, and the consumer knowledge). Hence, the remaining 87.8 percent is unaccounted for, which could be due to other variables which are not involved in this research study.

Table 3. ANOVAa

\begin{tabular}{llllll}
\hline Model & Sum of Squares & df & Mean Square & F & Sig \\
\hline Regression & 2.788 & 4 & .697 & 6.791 & $.000 \mathrm{~b}$ \\
Residual & 20.012 & 195 & .103 & & \\
Total & 22.800 & 199 & & & \\
\hline
\end{tabular}

a. Dependent Variable: NonperformingLoan

b. Predictors :( Constant), Consumer knowledge, Risk Perception, Customer Satisfaction, Compatibility.

From the ANOVA table 3, it was brightly stated that a significant result of 0.000 proved firmly that the ANOVA test is essential due to its F-value of 6.791 and the P-value is smaller than 0.05 . Thus, it was again proved that the ANOVA result that was obtained from this research shows good results.

Table 4. Coefficients

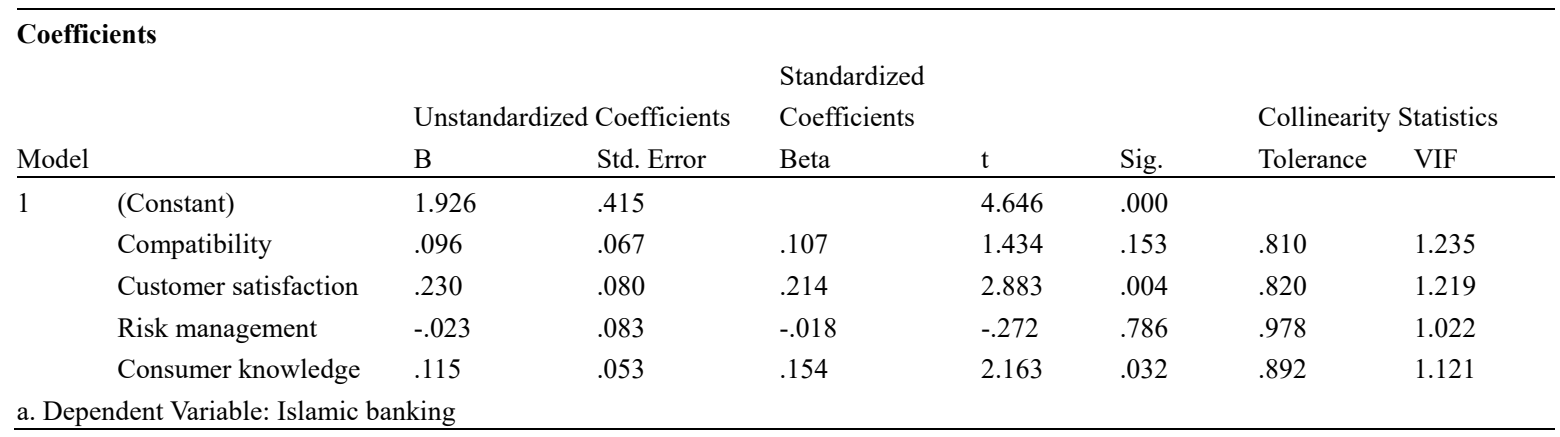

It is noteworthy from Table 4 that compatibility and risk perception/management does not seem to significantly influence adoption of Islamic Banking). However, there is enough evidence to support the claim that other three factors comprising customer satisfaction and consumer knowledge can significantly influence adoption of Islamic Banking in the Malaysian context.

The regression equation explaining the relationship between the independent variables and the dependent variable is captured as;

$$
\mathrm{Y}=\beta_{\mathrm{o}}+\beta 1 \mathrm{X}_{1}+\beta_{2} \mathrm{X}_{2}+\beta_{3} \mathrm{X}_{3}+\varepsilon
$$

Adoption of Islamic banking $=1.926+0.96$ (compatibility) +0.230 (customer satisfaction) -0.023 (risk 
management) +0.115 (consumer knowledge).

The table 4 conclude that two of the independent variables are significant and two of the independent variables are non-significant as the p-value of two of the independent variables are less than 0.05 and two are more than 0.05 . For instance, the p-value of the compatibility is 0.153 , p-value of the customer satisfaction is 0.004 , the $\mathrm{p}$-value of the risk management is 0.786 and the $\mathrm{p}$-value of the consumer knowledge is 0.032 . The next statistic is about the VIF. The value of the VIF has to be smaller or equal to 10 (VIF $\leq 10$ ), which will indicate that that there is no multicollinearity that exists among the variables. The table above shows that the VIF of compatibility is 1.235 , the VIF of customer satisfaction is 1.219 , the VIF of risk management is 1.022 and the VIF of the consumer knowledge is 1.121 .

\subsection{Hypotheses Result}

\begin{tabular}{|c|c|c|c|c|}
\hline & Hypothesis & Sig & Result & $\begin{array}{l}\text { Gradient } \\
(\text { Beta, } \beta)\end{array}$ \\
\hline $\mathrm{H}_{1} 1$ & $\begin{array}{l}\text { Compatibility does not have a direct significant influence on } \\
\text { adoption of Islamic banking in Malaysia }\end{array}$ & .153 & Not supported & .096 \\
\hline $\mathrm{H}_{1} 2$ & $\begin{array}{l}\text { Customer satisfaction have a direct significant influence on } \\
\text { adoption of Islamic banking in Malaysia }\end{array}$ & .004 & supported & .230 \\
\hline $\mathrm{H}_{1} 3$ & $\begin{array}{l}\text { Risk perception does not have a direct significant influence } \\
\text { on adoption of Islamic banking in Malaysia }\end{array}$ & .786 & Not Supported & -.023 \\
\hline $\mathrm{H}_{1} 4$ & $\begin{array}{l}\text { Consumer knowledge have a direct significant influence on } \\
\text { adoption of Islamic banking in Malaysia }\end{array}$ & .032 & Supported & .115 \\
\hline
\end{tabular}

\section{Discussion of Findings}

\subsection{Implication of the Study}

The findings and results of this study could bring upon some importance for certain groups of people, especially the consumers who use banking products and services and marketers who wants to advertise Islamic banking's products and services. It brings some benefits for the involved parties as they will have the opportunity to improve their performance in regards to the decision-making process in order to achieve benefits for both sides involved in a situation. The involved parties would be able to take more sensible and sound actions to achieve their objectives and to reach their objectives in the best manner.

\section{Conclusions and Recommendations}

The analysis made on the research findings completed in chapter four has helped to conclude that the independent variables, which consist of compatibility, customer satisfaction, and risk management and consumer knowledge can influence the consumer's adoption of Islamic banking. Thus, the Statistical Package for Social Scientists (SPSS) Version 22.0 plays a significant role in this study for the aim of conducting the necessary tests needed for this research such as descriptive analysis, normality test, z-score test, linearity test, correlation and multiple linear regression analysis to determine whether the relationship between the dependent variable and the independent variables are significant or not. The total of 200 questionnaires have been distributed and collected which have contributed to the findings of this research. The researcher found out that the citizens in Selangor, Malaysia prefer to the adoption of Islamic banking. Moreover, consumers believe that Islamic banking provide good products and services and they also believe that Islamic banking is compatible with some people, provides customer satisfaction and has fair risk management. Thus, Islamic banking could be an opportunity for the marketers.

The recommendation is that a replication of this study may be made at other educational institutions such as Multimedia University and Help University and also in universities located overseas and universities across the country as a mean to increase readers understanding towards factors influencing the adoption of Islamic banking. The reason is that it is possible to approach this research in an international aspect to let the researcher to acquire the comparison of the results and findings from varying geographical perspective. 


\section{References}

Amin, M., Isa, Z., \& Fontaine, R. (2013). Islamic banks: Contrasting the drivers of customer satisfaction on image, trust, and loyalty of Muslim and non-Muslim customers in Malaysia. International Journal of Bank Marketing, 31(2), 79-97. http://dx.doi.org/10.1108/02652321311298627

Cakarnis, J., \& D'Alessandro, S. P. (2015). Does knowing overcome wanting? The impact of consumer knowledge and materialism upon credit card selection with young consumers. Young Consumers, 16(1). http://dx.doi.org/10.1108/YC-01-2014-00418

Ganiyu, R. A., \& Adeosun, L. P. K. (2015). Perceived attributes of successful and unsuccessful Innovations. International Journal of Innovative Research in Management, 4(1).

Hair, J. F., Black, W. C., Babin, B. J., \& Anderson, R. E. (2010). Multivariate Data Analysis (7th ed.). Prentice Hall, Upper Saddle River, New Jersey.

Hamzah, N., Ishak, N. M., \& Mohd Nor, N. I. (2015) Customer Satisfactions on Islamic Banking System. Journal of Economics, Business and Management, 3(1).

Hristov, H., \& Kuhar, A, (2015). Subjective knowledge as a determinant of young adult consumers wine behavior. British Food Journal, 117(12). http://dx.doi.org/10.1108/BFJ-04-2015-0163

Illias, S. E. (2012). Risk Management in Islamic Banking. http://dx.doi.org/10.7763/IPEDR. 2012. V55.32

Jamshidi, D., Hussin, N., \& Hooi, L. (2015). Islamic banking services adoption as a new banking restructure. Humanomics, 31(2). http://dx.doi.org/10.1108/H-07-2013-0042

Jiang \& Rosenbloom. (2005). Customer intention to return online: price perception, attribute-level performance, and satisfaction unfolding over time. Eur. J. Mark., 39(1/2), 150-174. http://dx.doi.org/10.1108/03090560510572061

Kaura, V. (2013). Antecedents of customer satisfaction: A study of Indian public and privatesector banks. International Journal of Bank Marketing, 31(3). http://dx.doi.org/10.1108/02652321311315285

Narwal, M., \& Sachdeva, G. (2013). Impact of information technology (IT) on consumer purchase behavior. Journal of Arts, Science \& Commerce, 4(3).

Obeid, H., \& Kaabachi, S. (2016). Empirical Investigation Into Customer Adoption Of Islamic Banking Services In Tunisia. The Journal of Applied Business Research, 32(4).

Pillai, K. G., Brusco, M., Goldsmith, R., \& Hofacker, C. (2015). Consumer knowledge discrimination. European Journal of Marketing, $49(1 / 2)$.

Saad, N. M. (2012). Comparative analysis of customer satisfaction on Islamic and conventional banks in Malaysia. Asian Social Science, 8(1).

Sabir, R. I., Ghafoor, O., Akhtar, N., Hafeez, I., \& Rehman, A. U. (2014) Factors affecting customer satisfaction in banking sector of Pakistan, International Review of Management \& Business Research, 3(2).

Safeena, R., Date, H., Kammani, A., \& Hundewale, N. (2012) Technology Adoption and Indian Consumers: Study on Mobile Banking, International Journal of Computer Theory and Engineering, 4(6).

Tara, N., Irshad, M., Khan, M. R., Yamin, M., \& Rizwan, M. (2014). Factors Influencing Adoption of Islamic Banking: A Study from Pakistan. Journal of Public Administration and Governance, 4(3).

Yahaya, S., Yusoff, W. S. W., Idris, A. F., \& Haji-Othman, Y. (2014) Conceptual Framework for Adoption of Islamic Banking in Nigeria: The Role of Customer Involvement. European Journal of Business and Management, 6(30).

\section{Copyrights}

Copyright for this article is retained by the author(s), with first publication rights granted to the journal.

This is an open-access article distributed under the terms and conditions of the Creative Commons Attribution license (http://creativecommons.org/licenses/by/4.0/). 